"Impact of using humor advertisement on airline customers' mental image"

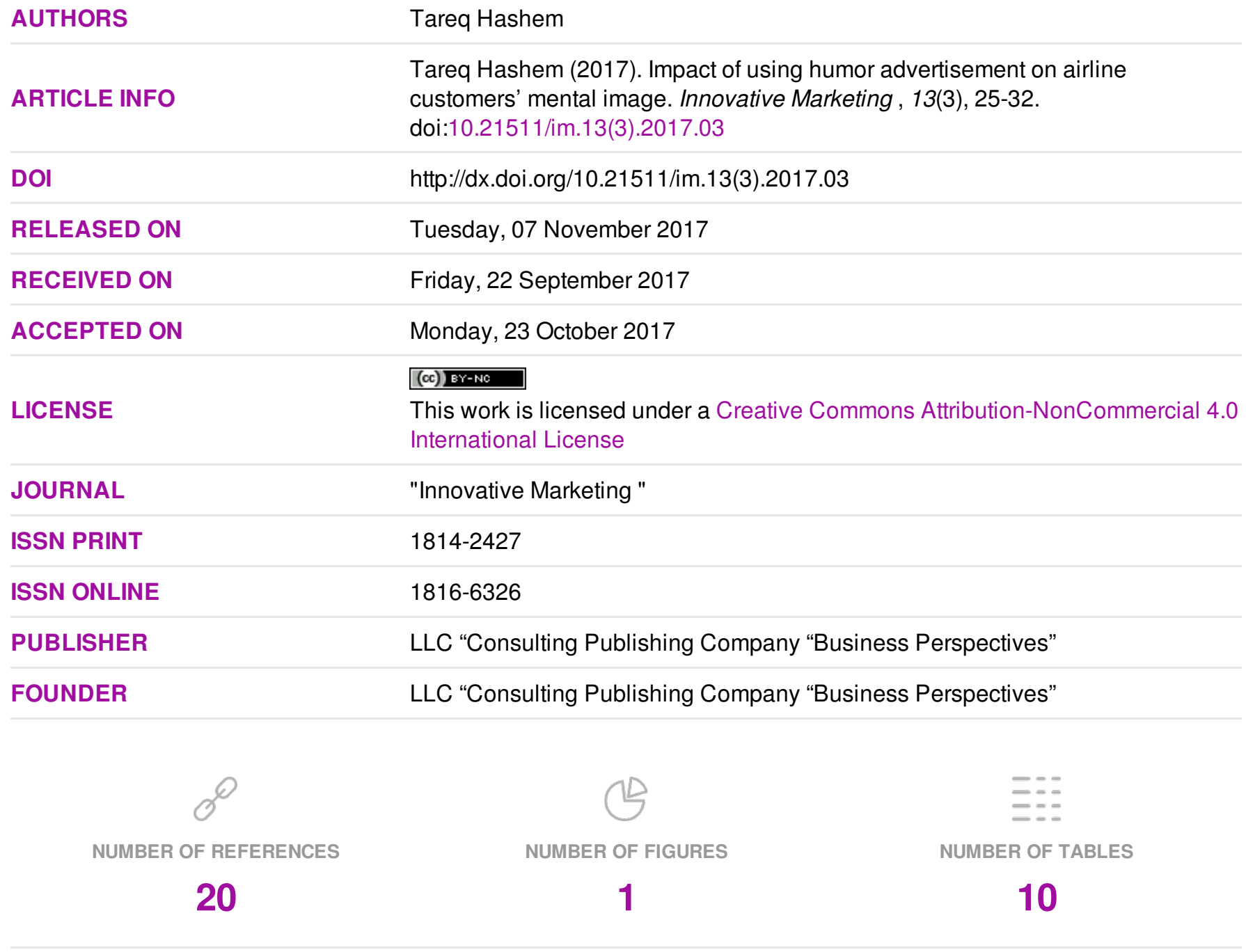

(C) The author(s) 2022. This publication is an open access article. 
Tareq Hashem (Jordan)

\title{
Impact of using humor advertisement on airline customers' mental image
}

\begin{abstract}
The study aims to investigate the impact of using humor advertisements on airline customers' mental image. To achieve the main objective, a questionnaire was designed according to research hypotheses. The study population consists of airline customers that operate in Jordan and those who were exposed to a humor advertisement on the planes. Each person was asked before filling the questionnaire if he was previously exposed during one of his flights to humor advertisement or not. A convenient sample of 700 people was selected, 587 valid questionnaires have been collected. The research concluded that humor advertising has a significant impact on the formation of airline customers' mental image, moreover, aggressive humor variable is considered the most influential variable on airline customers' mental image. The research suggested some recommendations, such as: airlines should adopt humorous marketing activities in high level, and to benefit from leading companies experiences in order to meet customer needs and desires. As well as, they should encourage customers to respond to them in expressing their opinion about humor advertisements they make.
\end{abstract}

Keywords: humor advertisement, mental image, affiliated humor, self-enhancement humor, self-defeating humor, aggressive humor.

JEL Classification: M3.

Received on: $22^{\text {nd }}$ of September, 2017.

Accepted on: $23^{\text {rd }}$ of October, 2017.

\section{Introduction}

Access to customers' feelings and impact on their mental image for purchase is of great importance, so various organizations are trying to use integrated marketing techniques based on humor as a way to increase their sales (Navrátilová \& Milichovský, 2015). Since humor has become one of the most widely used emotional appeals in universal advertising. Previous studies and researches have provided a variety of views on humor advertisement effects in increasing customer demand for products and services of various organizations (Chang \& Chang, 2014). In the same context, few studies and researches have attempted to analyze the emotional response of customers to humoristic advertisements (Limbu et al., 2012).

It is clear that business organizations are looking for all favors their continuation and growth and increasing their market share in order to gain customers marketing when facing the intensive competition. Recently, many modern business organizations in general have started flying companies to use humor in their ads as an effective communication tool with their customers. For example, New Zealand Airlines has replaced the

(C) Tareq Hashem, 2017.

Tareq Hashem, Dr. Associate Professor, Marketing Department, Isra University, Amman, Jordan.

This is an Open Access article, distributed under the terms of the Creative Commons Attribution-NonCommercial 4.0 International license, which permits re-use, distribution, and reproduction, provided the materials aren't used for commercial purposes and the original work is properly cited. boring instructions for passenger safety with videos that include fun humoristic scenes, which later become a strategy that be used by other airlines around the world. Companies use this strategy more than ever before to ensure that their customers are continually satisfied (Mathies et al., 2016). In Jordan, Royal Jordanian Airlines (RJ) launched this new type of marketing advertising for the first time in October 2016, before the US presidential election.

The results of many studies and researches in the field of advertising have confirmed the role of number of cognitive process, emotional and personal processes in formation and interpretation of humor. Each process highlights different aspects of customer motivations, which create a sense of humor. These processes provide an opportunity to interpret humor in the context of multiculturalism. However, various types of humor have been used successfully in advertising, although there is insufficient knowledge of the cultures diversity in some countries (Hatzithomas et al., 2011). Some studies and researches have indicated that humor advertisements always offer better results than nonhumor ones (Limbu et al., 2012; Lee, 2014). The most important marketing benefits of humor can be summarized as follows (Fugate, 1998; Venkatesh \& Senthilkumar, 2015; Upadhyaya, 2015; Djambaska et al., 2016; Mehmood \& Masood, 2016):

1. Increases customer attention.

2. Be more convincing to customers.

3. Enhances source credibility. 
4. Increase customer awareness and interest in products and services.

5. Contributes to customers convincing.

6. Enhances customers' good mood.

7. Reduces customer complaints.

According to Mathies et al. (2016), most of previous studies regarding the use of humor in advertising have identified many measures, but the most widely used metric is provided by Mathies et al. (2016), which includes four dimensions (the affiliative humor and humor of self-enhancement and selfdeprecating humor and aggressive humor), In this research it can be relied on as dimensions to measure the variable marketing humor for the comprehensiveness of all cases of positive and negative, and they can be illustrated as follows (Mathies et al., 2016):

1) Affiliated humor: this humor is targeting others in a positive way, and often arises in everyday situations, such as when people share funny stories. In social relationships, the affiliative humor can contribute to reducing unpleasant personal tensions, facilitating recognition of others, and increasing group cohesion. In light of this context, affiliative humor has extensive applications in marketing field to enhance meetings between service providers and customers, and it promotes building of good social relationships to add value to customers. At the same time, it is useful for service providers as it brings them to joy with high levels of self-esteem, emotional stability and caring for others.

2) Self-enhancing humor: it provides a mental defense mechanism by enabling people to deal with unpleasant situations or stress. Thus it provides positive effects that improve confidence and wellbeing and prevent clients depression. It can also be a successful strategy for service providers to reduce negative impacts in work environment. It is an effective way to deal with stressful situations well, so that it can provide a useful resource that increases the psychological well-being of service providers.

3) Self-defeating humor: this type of humor breaks down customers because it uses offensive jokes, and often expresses cynicism, and thus does not achieve the well-being of customers, because it is relatively frustrating self-confidence and desire to appreciate. So it is described as clearly aggressive and influenced by the level of emotional work of service providers.

4) Aggressive humor: it attempts deliberately to degrade customers. Examples of this kind of humor are obvious offensive jokes, discriminatory jokes, and inappropriate or degrading jokes, and thus lead to service failure.
According to Djambaska et al. (2016) the most important types of humor marketing can be illustrated as follows:

1. Funny marketing: humor depends on surprise dimension.

2. Marketing humor - emotional: humor depends on the peaceful excitement dimension.

3. Marketing humoristic - sarcastic: humor depends on routine dimension.

4. Marketing humor - comedy emotional: humor in it depends on excitement dimension.

5. Humor marketing - full comedy: humor depends on ordinal dimension and after excitement.

According to Chang and Chang (2014), humor marketing trends can be categorized into three directions:

1. Emotional orientation: The humor ads through some jokes tends to alleviate customers' bad mood and to reduce repressed negative emotions, resulting in a sense of relaxation and good feelings, and sense of humor.

2. Perception orientation: Dealing with contradictions or interpreting a number of conflicting messages can lead to humor development, which is based on contradictory decision theory.

3. Social orientation: This type of humor marketing orientation is based on excellence theory, which means that social situation resulting from humor will make customers realize that they are superior to others. Targeted customers by advertisements often feel superior.

Image. Image is defined as "the way the public perceives the company or its products" (Kotler \& Keller, 2006). A mental image means the image of a brand, brand or product in the minds of the target consumers in an appropriate market segment (Alaq, 2008). The decision to replace the mental image is of a strategic nature, not only for the organizations concerned with the provision of goods or services, but for the development or identification of other elements of the current marketing strategy such as pricing decisions, elements or tools of promotion and distribution outlets in addition to the decisions of the product (Obaidat, 2006; Nguyen, 2006).

The image consists of three interrelated elements that will be relied upon in this study (Al-Dhamour, Aish, 2005; Stephen, Omar, Abdul Wahid, Ismail, \& Harun, 2007):

- The cognitive image element is a set of beliefs about the thing that leads to an acceptable image, and the size of the external incentives plays a significant role in shaping the perceived image. 
Some may say that the image of an individual is more accurate than the image of another individual in case it relies on more real information.

- Affect element: relates to incentives in terms of how the individual evaluates the subject he wants, and the motivations determine what we want to get from the thing, which in turn affects the assessment of the object.

- The element of behavior and behavior (desire): the desire component of the image is similar to behavior, its direct relationship with other elements as it depends on the image created during the cognitive phase that is evaluated during the affect phase, and all the elements constitute the decision process.

Based on the above literature review, the main hypothesis is: Humor advertisement has a significant impact on airline customers' mental image.

\section{Research model}

Due to the above literature review, the researcher suggests the model presented in Figure 1.

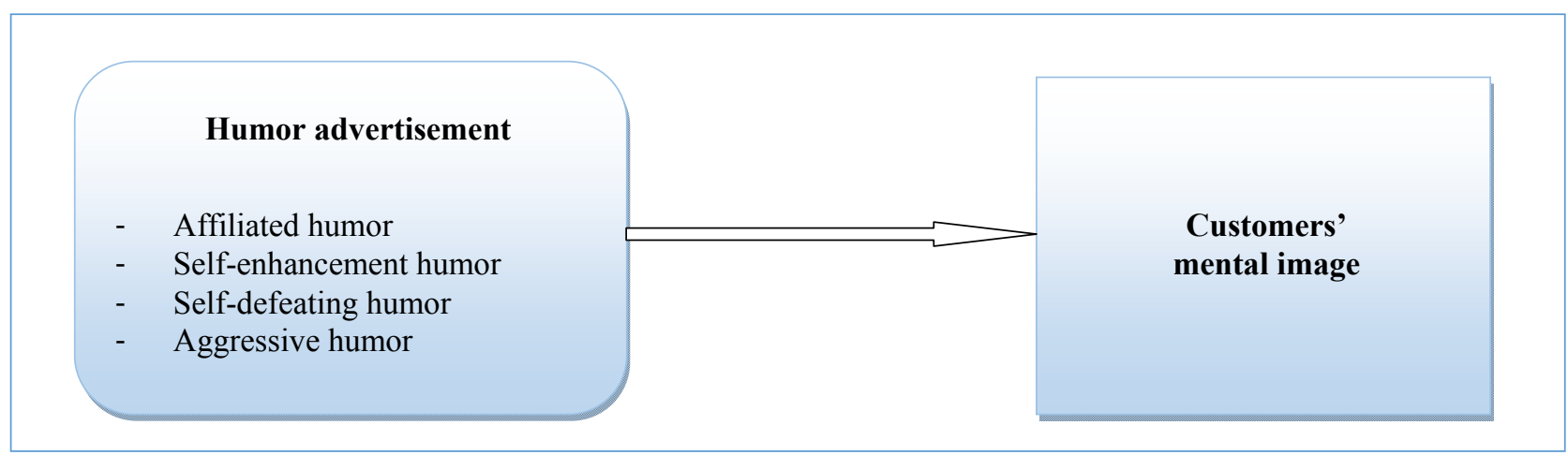

Fig. 1. Research model

Source: Mathies, Chiew, and Kleinaltenkamp (2016).

\section{Research methodology}

The research is based on descriptive analytical methodology to answer its questions and achieve its goals.

2.1. Research instrument. A questionnaire was prepared to collect the current research data consisting of two dimensions. The first dimension is related to demographic variables associated with research sample represented by gender, age, education level, and Monthly Average Income in USD. The second dimension includes a number of paragraphs related to the variables in question: the humor advertisement, which was based on Martin et al. (2003) and Mathies et al. (2016).

And the mental image airlines customers gave and it was based on the main indicators identified by the researcher (Hatch and Schultz, 1997), which included knowledge, feeling and believes.

Five point Likert scale was used as follows: strongly agree $=5$ points, agree $=4$ points, neutral $=3$ points, disagree $=2$ points, and strongly disagree $=1$ point .

2.2. Research population and sampling. The study population consists of airline customers that operate in Jordan and those who were exposed to a humor advertisement on the planes. Each person was asked before filling the questionnaire if he was previously exposed during one of his flights to humor advertisement or not. A convenient sample of 700 people was selected. The study questionnaire has been distributed. 587 valid questionnaires have been collected.

\section{Study sample characteristics}

Frequencies and percents for sample responses are as follows:

\subsection{Gender.}

Table 1. Study sample distribution according to gender

\begin{tabular}{|l|c|c|}
\hline \multicolumn{1}{|c|}{ Variable } & Frequency & Percent \\
\hline Male & 339 & $57.8 \%$ \\
\hline Female & 248 & $42.2 \%$ \\
\hline Total & 587 & $100 \%$ \\
\hline
\end{tabular}

Source: statistical processing.

Table 1 indicates that $57.8 \%$ of the sample are males, while $42.2 \%$ are females, which indicates a high proportion of males in the study sample.

\subsection{Age.}

Table 2. Study sample distribution according to age

\begin{tabular}{|l|c|c|}
\hline \multicolumn{1}{|c|}{ Options } & Frequency & Percent \\
\hline Less than 30 years & 98 & $16.7 \%$ \\
\hline 30 to less than 40 years & 229 & $39 \%$ \\
\hline 40 to less than 50 years & 196 & $33.4 \%$ \\
\hline $50+$ & 64 & $10.9 \%$ \\
\hline Total & 587 & $100 \%$ \\
\hline
\end{tabular}

Source: statistical processing. 
Table 2 indicates that $16.7 \%$ of the study sample age is less than 30 years, 39\% of the sample age is between $30-40$ years and $33.4 \%$ of the sample age is between $40-50$ years, $9 \%$ of the sample age is more than 50 years, which indicates high proportion of youth people.

\subsection{Educational level.}

Table 3. Study sample distribution according to educational level

\begin{tabular}{|l|c|c|}
\hline \multicolumn{1}{|c|}{ Option } & Frequency & Percent \\
\hline Secondary or Less & 82 & $10 \%$ \\
\hline Community Diploma & 78 & $13.3 \%$ \\
\hline BSC & 262 & $44.6 \%$ \\
\hline High Diploma & 54 & $9.2 \%$ \\
\hline MSC & 88 & $15 \%$ \\
\hline PhD & 23 & $3.9 \%$ \\
\hline Total & 587 & $100 \%$ \\
\hline
\end{tabular}

Source: statistical processing.

Table 3 indicates that $10 \%$ of the sample have secondary qualification or less, $13.3 \%$ have community diploma, $44.6 \%$ of the sample have bachelor's degree, $9.2 \%$ of the sample have high diploma on an average $15 \%$ of the sample have master degree, and $3.9 \%$ of the sample has doctoral, which indicates a high percentage of university qualification.

Table 4 indicates that $9.9 \%$ of the sample has a monthly average income of less than $\$ 500$, and that $5.5 \%$ of the sample has an average monthly income between 500 to less than $\$ 1000$, and $33.4 \%$ of the sample has a monthly average income between 1000 - to less than $\$ 1500$, and $47.5 \%$ of the sample has a monthly average income of more than $\$ 1500$. This indicates that the average monthly income of the sample study is high.

\subsection{Monthly average income in USD}

Table 4. Study sample distribution according monthly income

\begin{tabular}{|l|c|c|}
\hline \multicolumn{1}{|c|}{ Option } & Frequency & Percent \\
\hline Less than $\$ 500$ & 58 & $9.9 \%$ \\
\hline 500 to less than 1000 & 32 & $5.5 \%$ \\
\hline 1000 to less than 1500 & 196 & $33.4 \%$ \\
\hline $1500+$ & 279 & $47.5 \%$ \\
\hline No. Responses & 22 & $3.7 \%$ \\
\hline Total & 587 & $100 \%$ \\
\hline
\end{tabular}

Source: statistical processing.

\section{Reliability test}

A Cronbach Alpha test was used to ascertain instrument reliability. The value was $=0.936$ for the questionnaire. All values are accepted since they are more than 60\% (Malhotra, 2004).

\section{Study results}

Means and standard deviations, frequencies, and percents of the sample responses were calculated (Table 5).

\subsection{Affiliated humor.}

Table 5. Means and standard deviations of sample's responses regarding the affiliated humor variable

\begin{tabular}{|c|c|c|c|c|c|}
\hline Statements & $N$ & Minimum & Maximum & Mean & $\begin{array}{c}\text { Std. } \\
\text { deviation }\end{array}$ \\
\hline $\begin{array}{l}\text { I am very interested in introducing some marketing activities that make existing } \\
\text { customers laugh }\end{array}$ & 587 & 1.00 & 5.00 & 4.1158 & .87643 \\
\hline $\begin{array}{l}\text { Airlines are considered very moderate in offering some marketing activities } \\
\text { that make their current customers laugh }\end{array}$ & 587 & 1.00 & 5.00 & 3.5349 & .97410 \\
\hline $\begin{array}{l}\text { Airlines often make existing customers laugh by providing promotion programs } \\
\text { that we know }\end{array}$ & 587 & 1.00 & 5.00 & 3.5162 & 1.02577 \\
\hline $\begin{array}{l}\text { Airlines try to convey jokes or ridiculous situations to their current customers } \\
\text { through their advertisements }\end{array}$ & 587 & 1.00 & 5.00 & 3.6065 & 1.01196 \\
\hline $\begin{array}{l}\text { Airlines are trying to make current and prospective customers laugh when they } \\
\text { do some marketing activities }\end{array}$ & 587 & 1.00 & 5.00 & 3.6337 & 1.01713 \\
\hline General mean & 587 & 1.00 & 5.00 & 3.6814 & .70249 \\
\hline
\end{tabular}

Table 5 above indicates that there are positive attitudes since the sample means are more than the virtual mean 3 . It is also indicated that statement (I am very interested in introducing some marketing activities that make existing customers laugh) has the highest mean amounting 4.11, while paragraph 'Airlines often make existing customers laugh by providing promotion programs that we know' has the lowest mean amounting 3.52 . 


\subsection{Self-promotion humor.}

Table 6. Means and standard deviations of sample's responses regarding the self-promotion humor variable

\begin{tabular}{|l|c|c|c|c|c|}
\hline \multicolumn{1}{|c|}{ Statement } & N & Minimum & Maximum & Mean & $\begin{array}{c}\text { Std. } \\
\text { deviation }\end{array}$ \\
\hline $\begin{array}{l}\text { The airlines offer some advertising (applications) for jokes, which I can resort } \\
\text { to when I feel upset and sad. }\end{array}$ & 587 & 1.00 & 5.00 & 3.5366 & 1.00167 \\
\hline When I feel bad or unhappy, I usually try to watch airline ads & 587 & 1.00 & 5.00 & 3.6235 & .97038 \\
\hline $\begin{array}{l}\text { Airlines believe that the use of humor in the marketing field is the mean, which } \\
\text { achieves many goals on the personal level of their customers }\end{array}$ & 587 & 1.00 & 5.00 & 3.3714 & 1.04917 \\
\hline $\begin{array}{l}\text { I do not feel sad or upset when reading or watching some of commercial } \\
\text { marketing airlines programs }\end{array}$ & 587 & 1.00 & 5.00 & 3.5196 & .96219 \\
\hline $\begin{array}{l}\text { Airlines often try to use humor in some of their marketing activities as a very } \\
\text { effective way of dealing with or limiting their customers' problems }\end{array}$ & 587 & 1.00 & 5.00 & 3.4429 & 1.01595 \\
\hline General mean & 587 & 1.00 & 5.00 & 3.4988 & .70651 \\
\hline
\end{tabular}

Table above indicates that there are positive attitudes since the sample's means are more than the virtual mean 3 It is also indicated that statement 'When I feel bad or unhappy, I usually try to watch airline ads' has the highest mean amounting 3.62 while 'Airlines believe that the use of humor in the marketing field is the mean, which achieves many goals on the personal level of their customers' has the lowest mean amounting 3.37.

\subsection{Self-defeating humor.}

Table 7. Means and standard deviations of sample's responses regarding the self-defeating humor variable

\begin{tabular}{|c|c|c|c|c|c|}
\hline The airlines I deal with & $\mathrm{N}$ & Minimum & Maximum & Mean & $\begin{array}{c}\text { Std. } \\
\text { deviation }\end{array}$ \\
\hline $\begin{array}{l}\text { Do not make their customers through some of their marketing activities on } \\
\text { themselves laugh too much }\end{array}$ & 587 & 1.00 & 5.00 & 3.7121 & 1.02723 \\
\hline $\begin{array}{l}\text { Do not seek to use humor marketing activities that harm their customers and } \\
\text { put them feel psychological collapse }\end{array}$ & 587 & 1.00 & 5.00 & 3.5997 & .94465 \\
\hline $\begin{array}{l}\text { Have a desire to offer some marketing activities, by means of which their } \\
\text { customers feel respect and appreciation }\end{array}$ & 587 & 1.00 & 5.00 & 3.6934 & .95532 \\
\hline Do not provide any humor marketing activities that harm their customers & 587 & 1.00 & 5.00 & 3.6985 & .95248 \\
\hline $\begin{array}{l}\text { Do not exaggerate in the delivery of some ads, which include some jokes that } \\
\text { are not ridiculous }\end{array}$ & 587 & 1.00 & 5.00 & 3.7394 & .98549 \\
\hline General mean & 587 & 1.00 & 5.00 & 3.6886 & .68244 \\
\hline
\end{tabular}

Table 7 indicates that there are positive attitudes since the sample's means are more than the virtual mean 3. It is also indicated that paragraph 'Do not exaggerate in the delivery of some ads, which include some jokes that are not ridiculous' has the highest mean amounting 3.74, while statement 'Do not seek to use humor marketing activities that harm their customers and put them feel psychological collapse' has the lowest mean amounting 3.60.

\subsection{Aggressive humor.}

Table 8. Means and standard deviations of sample's responses regarding the aggressive humor variable

\begin{tabular}{|l|c|c|c|c|c|}
\hline \multicolumn{1}{|c|}{ The airlines I deal with } & N & Minimum & Maximum & Mean & $\begin{array}{c}\text { Std. } \\
\text { deviation }\end{array}$ \\
\hline Do not insult their customers through humor advertisements & 587 & 1.00 & 5.00 & 3.6678 & .94039 \\
\hline Are Interested in how customers interpret their humor marketing programs & 587 & 1.00 & 5.00 & 3.6201 & .97606 \\
\hline $\begin{array}{l}\text { Obscure some of their humor advertisements that are not appropriate for the } \\
\text { country's general situation }\end{array}$ & 587 & 1.00 & 5.00 & 3.7888 & .90298 \\
\hline $\begin{array}{l}\text { Do not use their competitors tactics from other companies to provide some } \\
\text { marketing activities that include jokes or blunt jokes }\end{array}$ & 587 & 1.00 & 5.00 & 3.6014 & .95166 \\
\hline Try to offer their marketing activities without abusing their customers & 587 & 1.00 & 5.00 & 3.6474 & .93838 \\
\hline General Mean & 587 & 1.00 & 5.00 & 3.6651 & .66614 \\
\hline
\end{tabular}

Table 8 indicates that there are positive attitudes since the sample's means are more than the virtual mean 3. It is also indicated that paragraph 'Obscure some of their humor advertisements that are not appropriate for the country's general situation' has the highest mean amounting 3.79, while paragraph 'Do not use their competitors tactics from other companies to provide some marketing activities that include jokes or blunt jokes' has the lowest mean amounting 3.60. 


\subsection{Mental image.}

Table 9. Means and standard deviations of sample's responses regarding the mental image variable

\begin{tabular}{|l|c|c|c|c|c|}
\hline \multicolumn{1}{|c|}{ Statement } & N & Minimum & Maximum & Mean & $\begin{array}{c}\text { Std. } \\
\text { deviation }\end{array}$ \\
\hline $\begin{array}{l}\text { 1. I speak positively about any airline that offers humor advertisements to my } \\
\text { friends and acquaintances }\end{array}$ & 587 & 1.00 & 5.00 & 3.6337 & .96372 \\
\hline 2. I do not look for other airlines & 587 & 1.00 & 5.00 & 3.6951 & .98661 \\
\hline $\begin{array}{l}\text { 3. I do not feel frustrated when dealing with an airline that offers humor } \\
\text { advertisements }\end{array}$ & 587 & 1.00 & 5.00 & 3.9012 & 1.05179 \\
\hline $\begin{array}{l}\text { 4. I feel that any airline offers humor advertisements through its ads is } \\
\text { successful }\end{array}$ & 587 & 1.00 & 5.00 & 3.8058 & .91056 \\
\hline $\begin{array}{l}\text { 5. I feel that any airline that offers humor advertisements through its ads is } \\
\text { distinct }\end{array}$ & 587 & 1.00 & 5.00 & 3.8194 & 1.01596 \\
\hline $\begin{array}{l}\text { 6. I am satisfied with the service provided by airline that offers humor } \\
\text { advertisements }\end{array}$ & 587 & 1.00 & 5.00 & 3.6917 & .96278 \\
\hline $\begin{array}{l}\text { 7.I have a good impression upon dealing with airline's website that offers humor } \\
\text { advertisements }\end{array}$ & 587 & 1.00 & 5.00 & 3.7666 & .96441 \\
\hline $\begin{array}{l}\text { 8. I have a positive perception towards the information provided by airline that } \\
\text { offers humor advertisements }\end{array}$ & 587 & 1.00 & 5.00 & 3.6661 & .93341 \\
\hline $\begin{array}{l}\text { 9. There is an increase in airline credibility level that offers humor } \\
\text { advertisements }\end{array}$ & 587 & 1.00 & 5.00 & 3.6457 & .98131 \\
\hline $\begin{array}{l}\text { 10. I have confidence in the information provided by the airline that offers humor } \\
\text { advertisements }\end{array}$ & 587 & 1.00 & 5.00 & 3.5111 & 1.00058 \\
\hline General Mean & 587 & 1.00 & 5.00 & 3.7136 & .66668 \\
\hline
\end{tabular}

Table above indicates that there are positive attitudes since the sample's means are more than the virtual mean (3).

\section{Main hypothesis}

The main hypothesis s respected in a tabulated form (Table 10).

Table 10. Humor advertisement has significant impact in airlines customers' mental image

\begin{tabular}{|c|c|c|c|c|}
\hline \multicolumn{5}{|c|}{ Model summary } \\
\hline Model & $\mathrm{R}$ & R square & Adjusted R square & Std. error of the estimate \\
\hline 1 & $.786 \mathrm{a}$ & .618 & .615 & .41346 \\
\hline
\end{tabular}

\begin{tabular}{|c|c|c|c|c|c|c|}
\hline \multicolumn{7}{|c|}{ ANOVA $^{a}$} \\
\hline & Model & Sum of squares & $\mathrm{df}$ & Mean square & $\mathrm{F}$ & Sig. \\
\hline \multirow{3}{*}{1} & Regression & 160.961 & 4 & 40.240 & 235.398 & $.000^{\mathrm{b}}$ \\
\hline & Residual & 99.490 & 582 & .171 & & \\
\hline & Total & 260.451 & 586 & & & \\
\hline
\end{tabular}

\begin{tabular}{|c|c|c|c|c|c|c|}
\hline \multicolumn{7}{|c|}{ Coefficients } \\
\hline & \multirow{2}{*}{ Model } & \multicolumn{2}{|c|}{ Unstandardized coefficients } & \multirow{2}{*}{$\begin{array}{c}\text { Standardized coefficients } \\
\text { Beta }\end{array}$} & \multirow{2}{*}{$t$} & \multirow{2}{*}{ Sig. } \\
\hline & & $B$ & Std. error & & & \\
\hline \multirow{5}{*}{1} & Constant & .419 & .110 & & 3.824 & .000 \\
\hline & Affiliated humor & .159 & .036 & .168 & 4.478 & .000 \\
\hline & Self-promotion humor & .154 & .038 & .163 & 4.092 & .000 \\
\hline & Self-defeating humor & .205 & .037 & .210 & 5.560 & .000 \\
\hline & Aggressive humor & .385 & .037 & .385 & 10.436 & .000 \\
\hline
\end{tabular}

The multiple regression test was used to test the above hypothesis. It was found that the calculated F-value = 235.398 was statistically significant at 0.05 level this indicates that the advertisement had a significant effect on the airline customers image. The strength of the relationship was 0.786 which has high impact; the tvalue for each variable is statistically significant at 0.05 level, which indicates that there is an impact of each variable on the dependent variable. The aggressive humor is the most influential variable on customers' mental image.

\section{Conclusion}

The study aims to investigate the impact of using humor advertisements on airlines customers' mental image. The study population consists of airline customers that operate in Jordan and those who were exposed to a humor advertisement on the 
planes. Each person was asked before filling the questionnaire if he was previously exposed during one of his flights to humor advertisement or not. A convenient sample of 700 people was selected, 587 valid questionnaires have been collected. The research drew many conclusions that are consistent with what was concluded in previous studies. The most notably are:

1. Airlines use very different humor advertisements nowadays.

2. Humor advertising has a significant impact on the formation of airline customers' mental image.

3. Aggressive humor variable is considered the most influential variable on airline customers' mental image.

The variable of self-promotion humor is the least influential ones on airline customers' mental image.
Due to the above conclusions, the author recommends that:

1. Airlines should highly adopt humorous marketing activities, and benefit from leading companies' experiences in order to meet customer needs and desires.

2. Airlines have to encourage customers to respond to them in expressing their opinion about humorous advertisements they make.

3. Airlines should take care of all the elements of humorous advertisement to achieve the customers' psychological satisfaction which helps in forming company's positive image.

4. Local airlines have to benefit from world's leading companies' experiences in application of humor marketing activities, and how to invest interaction between company and customers to form a good mental image.

5. To carry out studies that may be applied to other service sectors.

\section{References}

1. Alak, B. (2008). Marketing Planning. Jordan: Al-Yazuri Scientific Publishing House.

2. Al-Dhamour, H., \& Aish, H. (2005). Effect of the marketing mix of the five star hotels in Jordan on the image perceived by tourists: a comparative study. The Jordanian Journal of Business Administration, 1(1), 101-120.

3. Chang, W. Y., \& Chang, Y. (2014). The Influences of Humorous Advertising on Brand Popularity and Advertising Effects in the Tourism Industry. Sustainability, 6, 9205-9217. https://doi:10.3390/su6129205

4. Djambaska, A., Petrovska, I., \& Bundalevska, E. (2016). Is Humor Advertising Always Effective? Parameters for Effective Use of Humor in Advertising. Journal of Management Research, 8(1), 1-19. Retrieved from http://scialert.net/abstract/?doi=ajm.2016.8.21

5. Fugate, D. L. (1998). The advertising of services: what is an appropriate role for humor? Journal of Services Marketing, 12(6), 453-472. https://doi.org/10.1108/08876049810242731

6. Hatch, M., \& Schultz, M. (1997). Relations between organizational culture, identity and image. European Journal of Marketing, 3(5/6), 35-65.

7. Hatzithomas, L., Zotos, Y., \& Boutsouki, C. (2011). Humor and cultural values in print advertising: a crosscultural study. International Marketing Review, 28(1), 57-80. https://doi:10.1108/02651331111107107

8. Kotler, P., \& Keller, K. (2006). Marketing Management. New Jersey: Prentice Hall.

9. Lee, Y. (2014). How People Respond to Different Types of Humorous Advertising. British Journal of Economics, Management \& Trade, 4(9), 1419-1433.

10. Limbu Y. B., Huhmann B. A., \& Peterson, R. T. (2012). An examination of humor and endorser effects on consumers' responses to direct to-consumer advertising. The moderating role of product involvement. International Journal of Pharmaceutical and Healthcare Marketing, 6(1), 23-38. https://10.1108/17506121211216888

11. Malhotra, N. K. (2004). Marketing Research. New Jersey: Prentice Hall.

12. Martin, R. A., Puhlik-Doris, P., Larsen, G., Gray, J., \& Weir, K. (2003). Individual differences in uses of humor and their relation to psychological well-being: development of the humor styles questionnaire. Journal of Research in Personality, 37(1), 48-75. https://doi.org/10.1007/s10902-012-9342-6

13. Mathies, C., Chiew, T. M., \& Kleinaltenkamp, M. (2016). The antecedents and consequences of humour for service: A review and directions for research. Journal of Service Theory and Practice, 26(2), 137-162. https://doi.org/10.1108/JSTP-09-2014-0187.

14. Mehmood, H., \& Masood, S. (2016). Impact of Humor in Advertising on Consumer Purchase Intention: A Study on Ufone Network from Telecommunication Sector in Pakistan. International Review of Management and Business Research, 5(3), 1232-1240.

15. Navrátilová, L., \& Milichovský, F. (2015). Humour in Experiential Marketing Campaigns and its Perception by Czech University Students. Acta Universitatis Agriculturae et Silviculturae Mendelianae Brunensis, 63(2), 587593. http://dx.doi.org/10.11118/actaun201563020587

16. Nguyen, N. (2006). The collective impact of service workers and servicescape on the corporate image formation. Hospitality Management, 25, 227-244. Retrieved from http://www.sciencedirect.com/science/.

17. Obaidat, M. (2006). Contemporary Marketing Management. Jordan: National Library. 
18. Stephen, S., Omar, M., Abdul Wahid, N., Ismail, I., \& Harun, A. (2007). The effect of brand image on overall satisfaction and loyalty intention in the context of color cosmetic. Asian Academy of Management Journal, 12(1), 83-107.

19. Upadhyaya, M. (2015). The impact of humorous television advertisement in customer opinion in Bahrain. Indian Journal of Commerce \& Management Studies, 6(3), 20-25.

20. Venkatesh, S., \& Senthilkumar, N. (2015). Impact of Humor Advertising in Radio and Print Advertising - A Review. International Journal of Engineering Science and Innovative Technology (IJESIT), 4(2), $276-280$. Retrieved from https://mpra.ub.uni-muenchen.de/id/eprint/63979 